\title{
Mechanical behaviour of calcareous waste under consolidated drained triaxial compression testing in saturated conditions
}

\author{
Jakub Zięba ${ }^{*}$, \\ ${ }^{1}$ Cracow University of Technology, Faculty of Civil Engineering, Krakow, Poland
}

\begin{abstract}
The article presents the mechanical behaviour of calcareous waste under consolidated and drained condition in Triaxial compression test (CD). The host material currently being considered for the construction purpose of several buildings in Poland. One of the location of calcareous waste is in Łagiewniki area (in Cracow) [1,2]. In this work, particular attention has been paid to the to ensure fully saturation for all the tested soil samples and avoid generation of unwanted excess pore water pressure during shearing stage. The saturation level of soil samples was estimated based on Skempton's law (B $>0.95)$. CD Triaxial test have been conducted in order to derive information on its strength and stiffness properties.
\end{abstract}

Keywords: calcareous waste, CD Triaxial test, mechanical behaviour

\section{Introduction}

Nowadays Poland (Ciech) [3] with production capacity at 150 thousand tonnes per year of baking soda is the second largest producer in Europe. Over the last several decades, in Poland located was also Solvay Plant (Cracow) and smaller chemical factories producing soda. As a result of the activity of companies by that time, several sediments tanks witch calcareous waste were created. Due to the applied production technology of baking soda, production residues are calcareous wastes. The main element of the anthropogenic soil is calcium carbonate $\left(\mathrm{CaCO}_{3}\right)$, which occurs together with silicon oxides $\left(\mathrm{SiSO}_{2}\right)$ and other substances (i.e. $\mathrm{P}_{2} \mathrm{O}_{5}, \mathrm{CaSO}_{4}, \mathrm{MgSO}_{4}, \mathrm{BaSO}_{4}, \mathrm{NaCl}, \mathrm{CaCl}_{2}$ [4]). Due to the high content of calcium carbonate, the soil has a white colour and that's why these tanks are called "White Seas". The largest calcareous wastes tanks in Poland are located in Cracow, Janików, Mątwy and in the vicinity of the Jaworzno. In Cracow in recent years reclamation process was done. Sedimentations tanks in Janików and Mątwy (the part of the "Ciech Group") are still open.

The possibility of using the anthropogenic soil, such as calcareous waste, for the construction purpose, requires knowledge of the mechanical behaviour during compression test. The tested soil is very difficult to characterize, because characterised witch soft

${ }^{*}$ Corresponding author: jzieba@pk.edu.pl 
consistency and various level of water content. One of the major challenges in the experimental testing of calcareous wastes soil was the exposure of the material to the atmosphere before preservation and the time required for a careful preparation of specimens induce a loss of water content and a reduction in the degree of saturation.

\section{Material and Methodology}

The CD Triaxial tests were done at the Laboratory Soil - Structure Interaction Division, Cracow University of Technology. The tested soil, was presented in detail in the author's articles in previous years [2,5]. The averaged results of the initial physical parameters are presented below in Tab. 1.

Table 1. Initial physical parameters of the calcareous waste soil.

\begin{tabular}{|c|c|c|c|c|c|}
\hline Soil & $\begin{array}{c}\text { Bulk } \\
\text { density } \\
{\left[\mathbf{g} / \mathbf{c m}^{3}\right]}\end{array}$ & $\begin{array}{c}\text { Water } \\
\text { content } \\
{[\%]}\end{array}$ & $\begin{array}{c}\text { Specific } \\
\text { gravity } \\
{\left[\mathbf{g} / \mathbf{c m}^{3}\right]}\end{array}$ & $\begin{array}{c}\text { Porosity } \\
{[-]}\end{array}$ & $\begin{array}{c}\text { Degree of } \\
\text { saturation } \\
{[-]}\end{array}$ \\
\hline $\begin{array}{c}\text { calcareous } \\
\text { wastes }\end{array}$ & 1,45 & 75 & 2,64 & 0,65 & 0,79 \\
\hline
\end{tabular}

The main particle fraction of post-distillated and post brined calcareous waste was silt. The deposited waste normally stood at a height of nearly 20 meters sedimentation tanks (sometimes the height reached almost $30 \mathrm{~m}$ ).

All laboratory CD Triaxial compression tests were carried out according to British Standard 1337 Part 8 [6]. This Part of BS 1377 specifies procedures for the determination of the effective shear strength parameters of tested samples.

\section{Consolidated Drained Triaxial Compression Testing}

The following sections describe in detail the different stage of the testing procedure. Consolidated Drained Triaxial Compression tests comprise three main stages: (1) saturation with B-check test, (2) isotropic consolidation and final (3) compression in drained condition. The three stages are described in detail in the following sections.

\subsection{Soil samples}

Soil blocks were extracted at a depth of approximately $16 \mathrm{~m}$ (sample $\mathrm{P} 1 \div \mathrm{P} 3$ ) and $10 \mathrm{~m}$

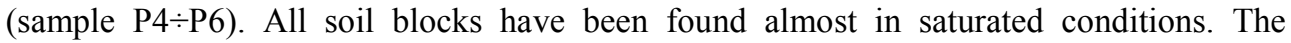
samples with dimensions: diameter $50 \mathrm{~mm}$ and height about $80 \mathrm{~mm}$ were trimmed carefully from the soil block before starting the test. The height before each test was determined individually. Filter paper strips were placed over the specimens to accelerate saturation and consolidation process.

\subsection{Saturation with B-check test}

Specimens were saturated using a back pressure method. In this method, increments of cell pressure and back pressure are applied alternately. The B-check test consists in measuring the B-Skempton pore water pressure coefficient [7], which is defined as the ratio between the pore water pressure variation and the mean total stress variation when isotropic 
compression is carried out in undrained conditions. A mean total stress increment of $50 \mathrm{kPa}$ has been selected for all the B-check tests. The sample P1 were saturated with a cell pressure of $350 \mathrm{kPa}$ and $\mathrm{B}$-value checks all exceeded 0.96 . On the last step of B-check pore water presser increase $48 \mathrm{kPa}$ (from 290 to $338 \mathrm{kPa}$ ). Total time of saturation stage was $8 \mathrm{~h}$. The saturation and the B-check test on specimen $\mathrm{P} 1$ is depicted in Fig. 1 as an example of the adopted procedure.

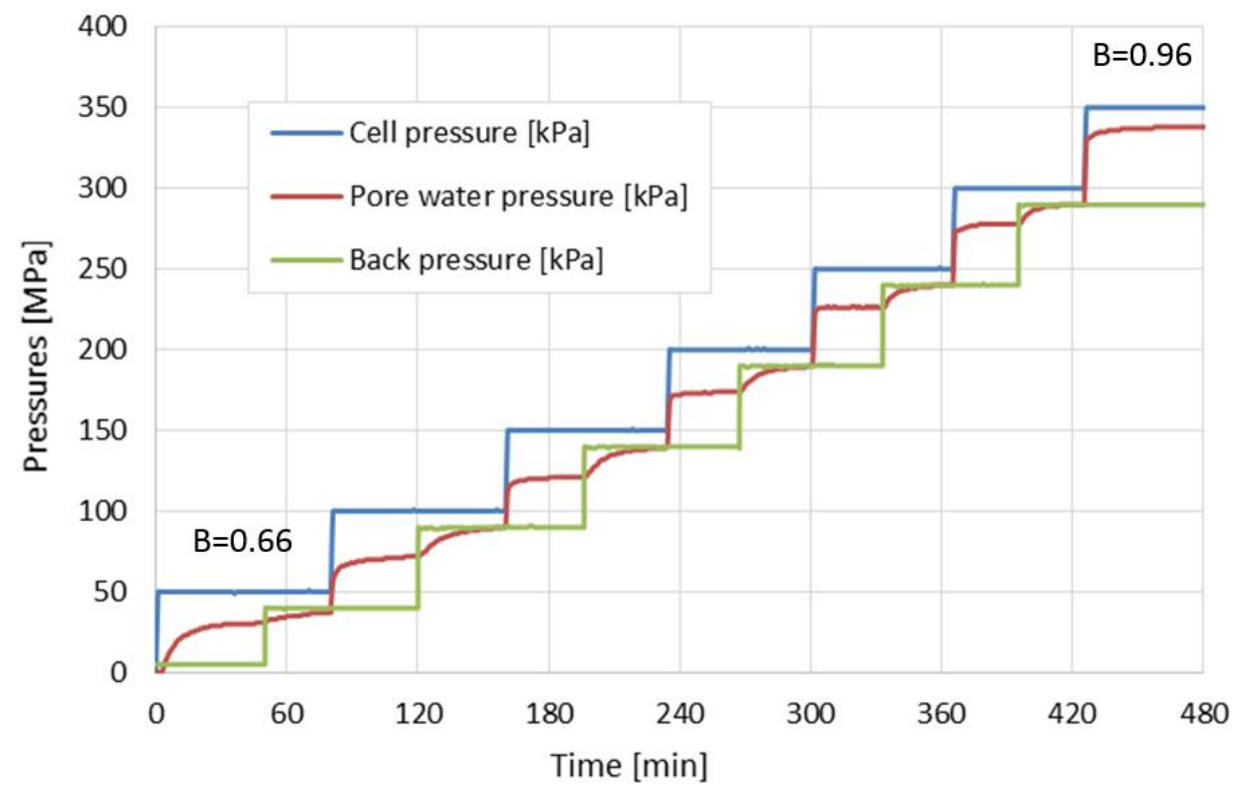

Fig. 1. Saturation stage with B-check test for Sample P1: increment in mean total stress and evolution of cell pressure, pore water pressure and back pressure in time

Finally the achievement of saturated conditions in tested samples was ensured through the performance of B-check tests. For samples P $\div$ P6

\subsection{Isotropic consolidation}

After B-check was accomplished, drained conditions were established by opening the drainage valves (back pressure). Subsequently, the specimen was isotropically loaded to the desired confining pressure, and enough time was allowed for ensuring the dissipation of the generated excess pore water pressures. A constant water cell and back pressure was maintained throughout the consolidation stage of the tests. For both tests confining pressure was 100,200 and $300 \mathrm{kPa}$.

During the stage change of pore water pressure and volume of the specimen was recorded. Specimens were isotropically compressed until pressure in the sample was fully dissipated. The primary consolidation phase in first 36 min was noticed. The rest of time the secondary compression phase also was noticed. Total time of consolidation was $5,5 \mathrm{~h}$. The consolidation stage on specimen P1 is depicted in Fig. 2 as an example of the adopted procedure. 


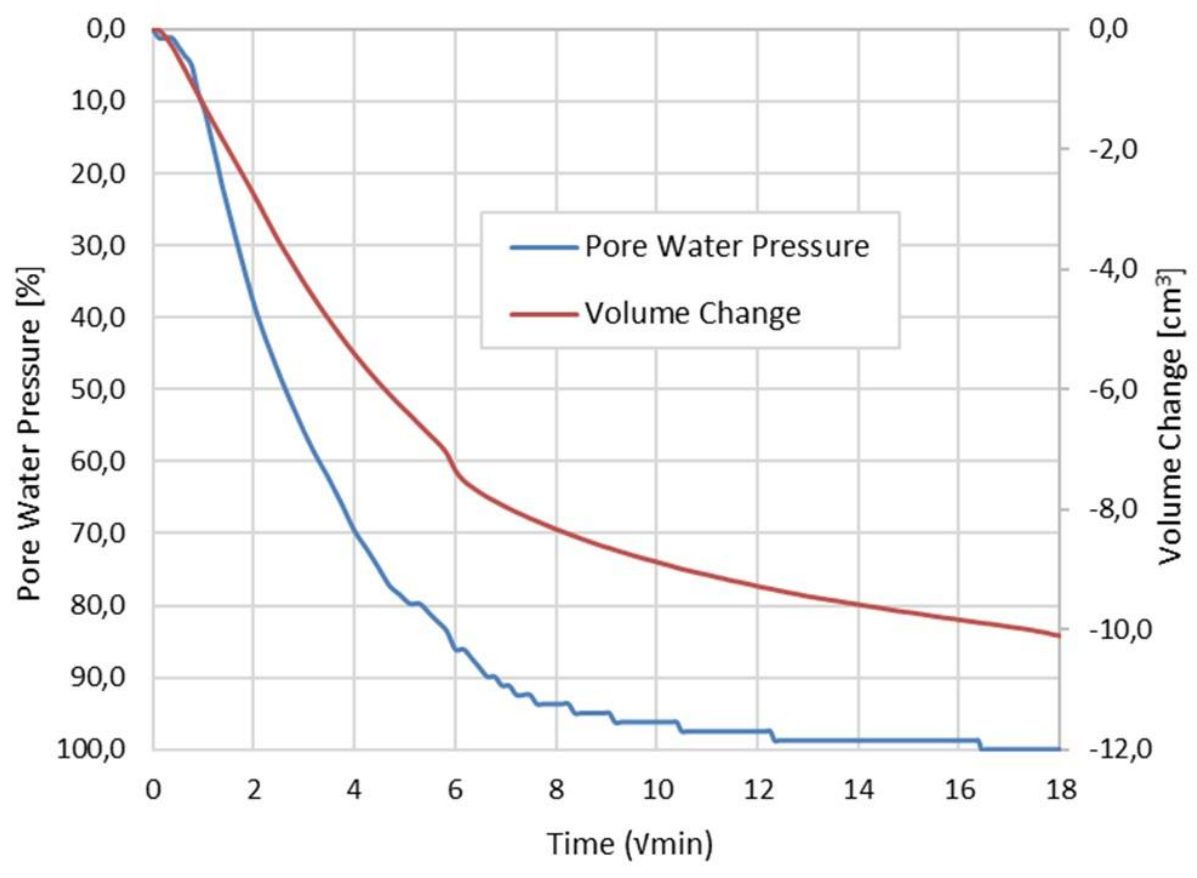

Fig. 2. Consolidation stage for Sample P1: increment in mean total stress and evolution of cell pressure, pore water pressure and back pressure in time

As the results of consolidation stage is consolidation curve measured volume change against square-root time. The volume-change indicator and for sample P1 was $10.13\left[\mathrm{~cm}^{3}\right]$ so the volumetric Strain was 7.08 [\%]. In the next samples volumetric stains they reached value between 6 and even $20 \%$.

The main goal of the isotropic consolidation stage is reached confining effective stress in tested sample, but also estimate the maximum rate of axial displacement The rate of axial displacement $[\mathrm{mm} / \mathrm{min}$ ] applied to the specimen in next stage was calculated from the following equation [6]:

$$
d_{r}=\frac{\varepsilon_{f} * L_{C}}{F * t_{100}}
$$

where $\varepsilon_{\mathrm{f}}$ is the significant strain interval $\mathrm{L}_{\mathrm{c}}$ is the length of the consolidated specimen [mm], $\mathrm{F}$ is a coefficient related to the drainage conditions and equal to 14 for drainage from radial boundary and one end of the specimen and $t_{100}$ is the time at the end of the primary consolidation phase. Equation 1 gives the maximum nominal machine speed for the next stage. The speed range before each test was determined individually. 


\subsection{Compression in drained condition}

The finale stage of Triaxial test was compression in drained condition. For this stage call and back pressure was maintained. For all the tests, a frame speed range between of $0,003 \div 0,008[\mathrm{~mm} / \mathrm{min}]$ was adopted. The results of compressing of samples in triaxial cell is axial strass versus axial strain presented in Fig. 3.

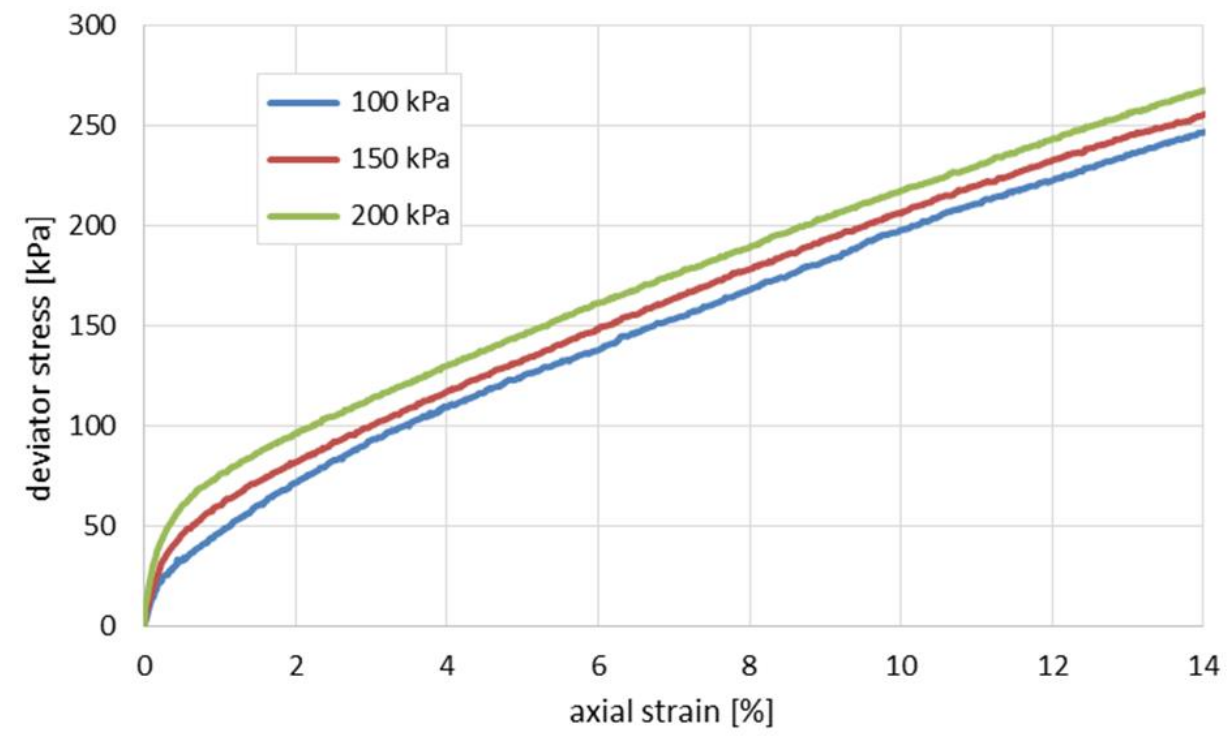

Fig. 3. Stress-strain curve for samples $\mathrm{P} 1 \div \mathrm{P} 3$ : deviator stress $\mathrm{q}[\mathrm{kPa}]$ versus axial strain $\varepsilon_{\mathrm{a}}[\%]$

However, in spite of the fact of very small speed of shearing the increase in pore water pressure was noticed. The pore water pressure increase from $1 \%$ strain to $10 \%$ constantly and it has changed from $300[\mathrm{kPa}]$ to $306[\mathrm{kPa}]$ (increment of $6[\mathrm{kPa}]$ ). Once the $10 \%$ strain has been reached, the pore pressure has not changed and remains constant. The same situation in rest of samples was noticed. The change of pore water pressure during compressing stage affects in further analysis.

The results from CD triaxial compression shear tests can be plotted in various formats. One useful format as Mohr Circles is to plot the data of minor and major effective principal stress space. If the pore water pressure at failure is known, the effective principal stresses $\sigma_{1}$ ' and $\sigma_{3}{ }^{\prime}$ can be calculated and the corresponding effective Mohr Circles drawn. The results has been presented in Fig. 4.

The next useful format is to plot the data in stress path space [8], by plotting the mean effective stress s' $[\mathrm{kPa}]$ and deviatoric stresses t' $[\mathrm{kPa}]$. The stress path parameters (in terms of effective stress) can be established from the following equations:

$$
\begin{aligned}
& s^{\prime}=1 / 2\left(\sigma_{1}{ }^{\prime}+\sigma_{3}{ }^{\prime}\right) \\
& t^{\prime}=1 / 2\left(\sigma_{1}{ }^{\prime}-\sigma_{3}{ }^{\prime}\right)
\end{aligned}
$$

where, $\sigma_{3}[\mathrm{kPa}]$ is the cell confining pressure, and $\sigma_{1}-\sigma_{3}[\mathrm{kPa}]$ is a deviator stress. Plotting the data in stress path space allows to observe the behaviour of calcareous waste under shear. The results has been presented in Fig. 5. 


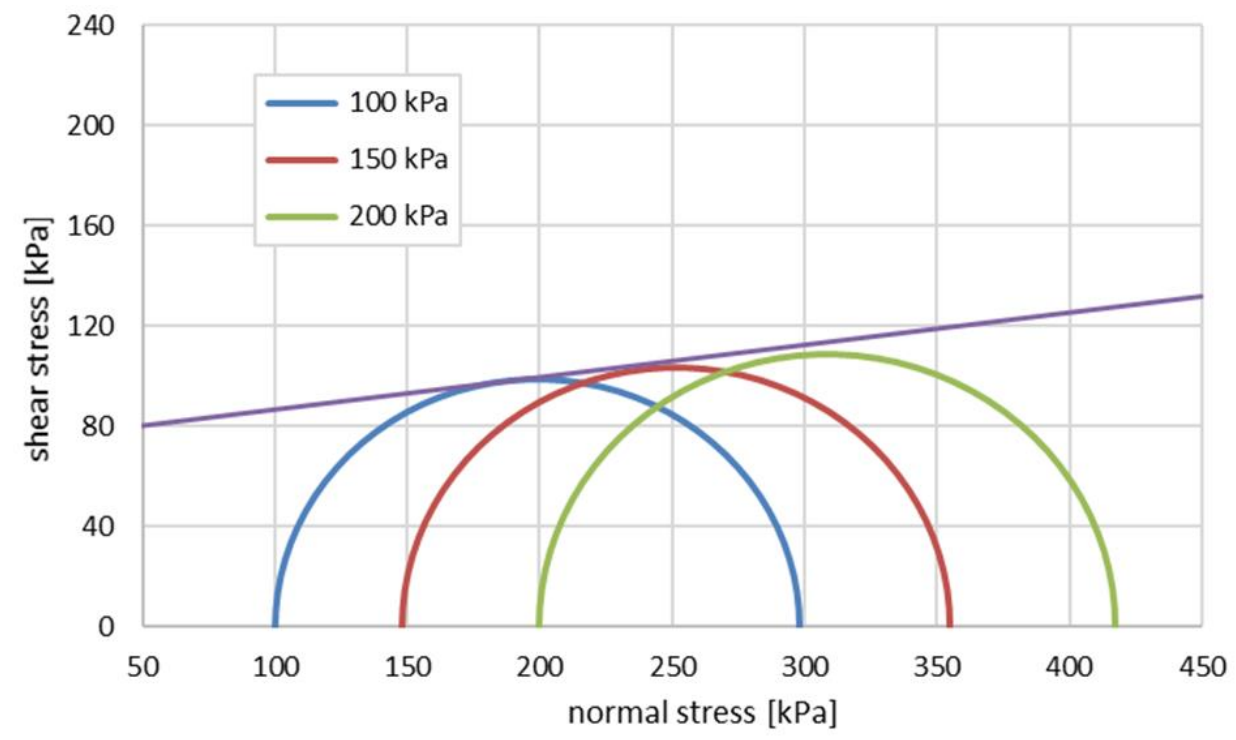

Fig. 4. Effective Mohr Circles at $10 \%$ strains: normal effective stress $[\mathrm{kPa}]$ versus shear stress $[\mathrm{kPa}]$

The effective stress parameters, representing the drained strength of the $\mathrm{P} 1 \div \mathrm{P} 3$ calcareous waste samples, are as follows: $\phi^{\prime}=8[\mathrm{deg}]$ and c' $=70[\mathrm{kPa}]$. The result of the test for samples P4 $\div \mathrm{P} 6$, was: $\phi^{\prime}=7[\mathrm{deg}]$ and c' $=60[\mathrm{kPa}]$. The CD Triaxial test reveals that the effective shear strength parameters are higher for deeper samples.

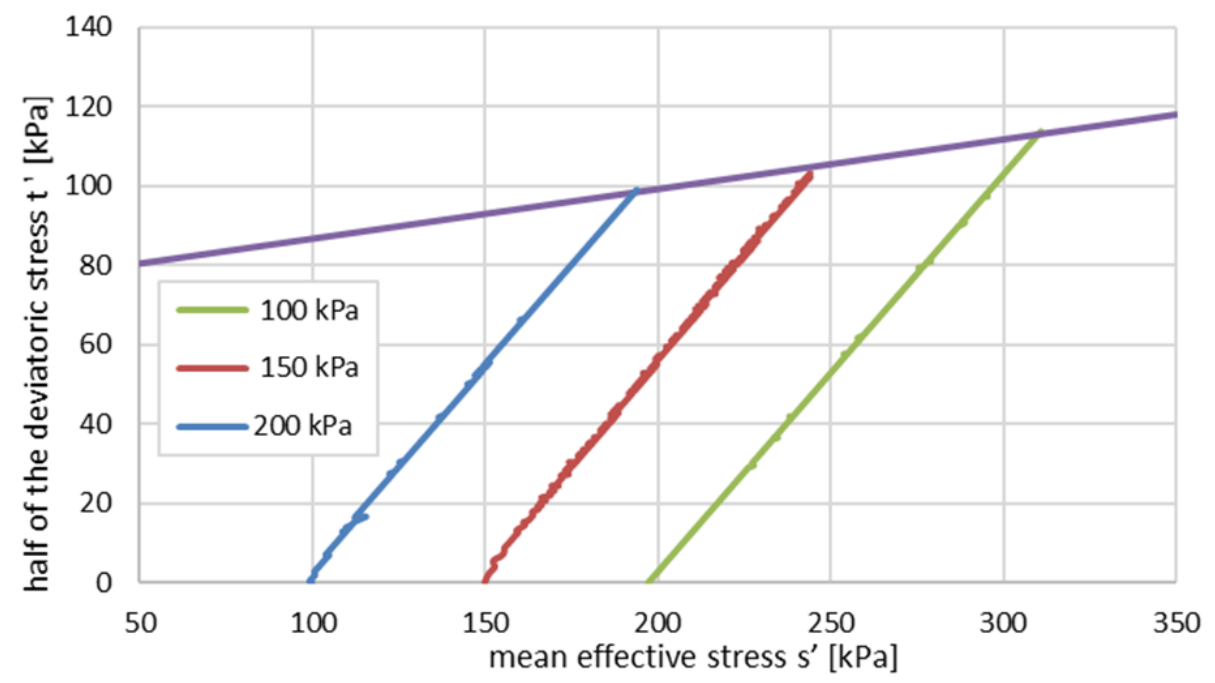

Fig. 5. Stress path parameters, s' and t' $[\mathrm{kPa}]$ to $10 \%$ strains: the mean effective stress s' $[\mathrm{kPa}]$ and deviatoric stresses $\mathrm{t}^{\prime}[\mathrm{kPa}]$

The results presented in Fig. 5 were used also to calculate the values of the effective friction angle and effective cohesion intercept at $10 \%$ levels of axial strain. 
Because calcareous waste are nonlinear materials, the secant modulus depends on the mean strain level. Secant modulus of tested soil decrease as the strain level increases (the stress strain curve has a downward curvature [9]). The secant modulus can be established from the following equations:

$$
E_{S}=\frac{\Delta q_{i}}{\Delta \varepsilon_{a i}}
$$

The results of calculation has been presented in Fig. 6 .

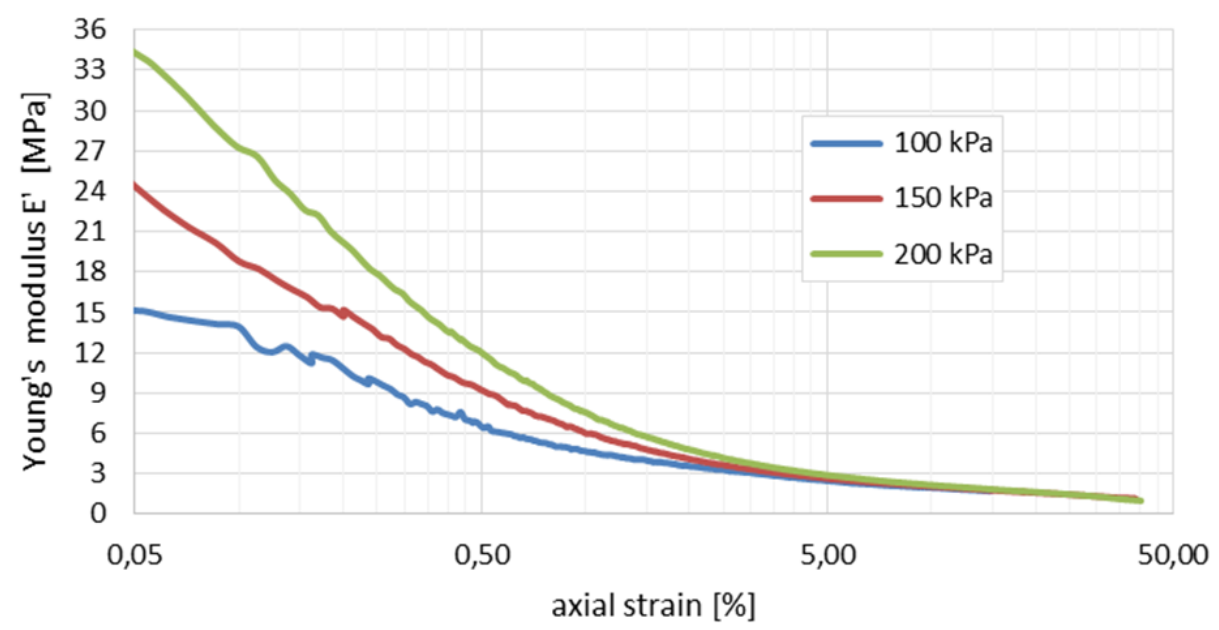

Fig. 6. Determination of secant modulus of deformation for samples P1 $\div$ P3: secant modulus of deformation $\mathrm{E}^{\prime}[\mathrm{MPa}]$ versus axial strain $\varepsilon_{\mathrm{a}}[\%]$

The modulus of deformation for the tested material is observed to be stress dependent. In small strains zone (between 0,05 and $0,5 \%$ ) the modulus of deformation is highly dependent form confining effective stress. In range between 4 and $40 \%$ strain secant modulus of deformation were comparable between each sample. The moduli of deformation is typical for soft silts [10].

\section{Results and analysis}

The results of the tests for calcareous waste under consolidated drained triaxial compression test in saturated conditions was presented in article. This study investigated and effective shear strength parameters and the elastic moduli, which is important for further geomechanical modelling. A clear isotropic elastic behaviour has been observed for the tested samples, The study concluded the following:

- stress-strain curve as an elastic-plastic with strain hardening

- yield strain reached at $0,2 \%$

- effective friction of angle was 8 [deg] for $\mathrm{P} 1 \div \mathrm{P} 3$ and 7 [deg] for $\mathrm{P} 4 \div \mathrm{P} 6$ samples

- effective cohesion was $70[\mathrm{kPa}]$ for $\mathrm{P} 1 \div \mathrm{P} 3$ and $60[\mathrm{kPa}]$ for $\mathrm{P} 4 \div \mathrm{P} 6$ samples

- the modulus of deformation is stress dependent

- volumetric stains reached value between 6 and even 20\% during consolidation stage 
The results presented in this paper are obtained following meticulous experimental procedures ( $\mathrm{CD}$ triaxial test), and they have been analysed in order to derive relevant parameters for the prediction of the mechanical behaviour of calcareous waste.

This study is believed to be important for the successful design of civil and transportation structures, where the correct knowledge of the stiffness and strength behaviour of calcareous waste plays a key role.

\section{References}

1. B. Czado, Analiza nośności pali fundamentowych na podstawie polowych badań gruntów sonda statyczna (Analysis of bearing capacity of foundation piles based on field cone penetration tests results), Rozprawa doktorska, Biblioteka Politechniki Krakowskiej (2014) (in Polish)

2. E. Pilecka, J. Zięba "Preliminary studies of the dynamic stiffness modules of soil samples from the Solvay Sodium Plant waste landfill in Krakow", E3S Web of Conferences (2017), doi: 10.1051/e3sconf/20172402006

3. https://ciechgroup.com

4. I. Krzak, Zagospodarowanie terenów poprzemystowych Krakowskich Zakładów Sodowych ,, Solvay” (Post - industry reclamation of Cracow Soda Industry ,, Solvay”), Problemy Ekologii Krajobrazu, 17, 283-287 (2005) (in Polish)

5. E. Pilecka, J. Zięba, R. Pilecki "S-wave velocity in samples of calcareous waste”, E3S Web of Conferences (2017), doi: 10.1051/e3sconf/20186602005

6. BS 1377-8 "Methods of test for soils for civil engineering purposes. Shear strength tests (effective stress)", British Standards Institution, London (1990)

7. A. W. Skempton, "The Pore-Pressure Coefficients A and B”, Geotechnique 4:4, 143147 (1954), doi: 10.1680/geot.1954.4.4.143

8. Lambe, T.W., "Stress Path Method”, Jnl. Soil Mech. \& Found. Division, ASCE, Vol. 93, No. SM6, 309-331 (1967).

9. G. Ranjan, A. S. R. Rao: Basic and Applied Soil Mechanics. New Age International, 2000, chapter 10, $287 \div 352$. ISBN: 8122412238, 9788122412239

10. P. J. Vardanega, d M. D. Bolton, „Stiffness of Clays and Silts: Normalizing Shear Modulus and Shear Strain", Journal of Geotechnical \& Geoenvironmental

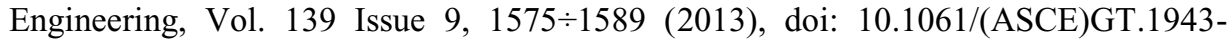
5606.0000887 